The essays in this volume explore the nature of time, our God-given medium of ascent, known, as Augustine puts it, through the ordered study of the "liberal disciplines that carry the mind to the divine (disciplinae liberales intellectum efferunt ad divina)": grammar and dialectic, for example, to promote thinking; geometry and astronomy to grasp the dimensions of our reality;
music, an invisible substance like time itself, as an exemplary bridge to the unseen substance music, an invisible substance like time itself, as an exemplary bridge to the unseen substance
of thoughts, ideas, and the nature of God (theology). This ascending course of study rests on procedure, progress, and attainment - on before, following, and afterwards - whose goal is an ascending erudition that lets us finally contemplate, as Augustine says in De ordine, our invisible medium - time - within time itself: time is immaterial, but experienced as substantial. The essays here look at projects that chronicle time "from the beginning," that clarify ideas of creation "in time" and "simultaneous times," and the interrelationships between measured time and eternity, including "no-time." Essays also examine time as revealed in social and political contexts, as told by clocks, as notated in music and embodied in memorializing stone. In the

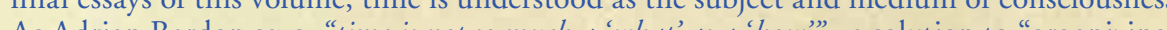
experience and modeling events.

Contributors are (in order within the volume) Jesse W. Torgerson, Ken A. Grant, Danielle B. Joyner, Nancy van Deusen, Peter Casarella, Aaron Canty, Jordan Kirk, Vera von der OstenSacken, Gehlard Jariz, Jason Aleksander, Sara E. Melzer, Mark Howard, Andrew Eschelbache, Hans J. Rindisbacher, James F. Knapp, Peggy A. Knapp, Raymond Knapp, Michael Cole, Ike

NANCY VAN DEUSEN holds a Ph.D. in Musicology, Indiana University, Bloomington; is currently Professor of Musicology, Benezet Professor of the Humanities, Claremont Graduate University, and is Director of the Claremont Consortium in Medieval and Early Modern Studies, Claremont Colleges and Graduate University. She has taught widely at Indiana Central European University. Budapest, and within the California State University system. She has received American Philosophical Society, numerous NEH, and Fulbright grants; an has published on music within the medieval city of Rome, music, liturgy, and institutional. structure within the medieval cathedral milieu of Nevers, France, the medieval sequence within ideas; music as medieval science and within the curriculum of the early university.

LEONARD MICHAEL KOFF $\rightarrow$ holds a B.A. and M.A. from Columbia University and an M.A. and Ph.D. from the University of California, Berkeley. He is an Associate of the Center for Medieval and Renaissance Studies, UCLA, where he has taught and developed courses on campus and online, including Homer and James Joyce, the Literature of Existentialism, humanities sequence. He has published Chaucer and the Art of Storytelling essays on medieval literature and medievalism, and lectured in this country and Europe on such subjects as literature and philosophy, the shared texts of Western religious identity (Jewish, Christian, Islamic), theories of translation, Cicero, Freud, and Emmanuel Levinas - and distance learning for the Ministry of Higher Education, Iraqi Kurdistan. He is co-editor of The Decameron and the Canterbury Yales. New Essays on an Old Question, as well as co-editor of Mobs from Bill

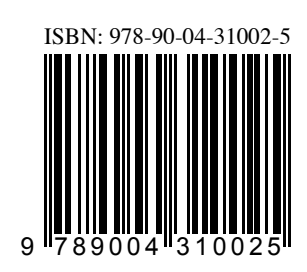

ISSN 1875-2799 brill.com/pthp

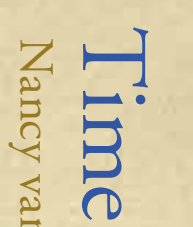

$\forall$

$\sum_{\substack{0 \\ 0}}^{3}$

$\stackrel{5}{1}$

$\frac{5}{8}$

3

స్ㅠㅁำ

옹

त्र

CENTR AL ISSUES IN MEDIEVAL

STUDIES ACROSS THE DISCIPLINES

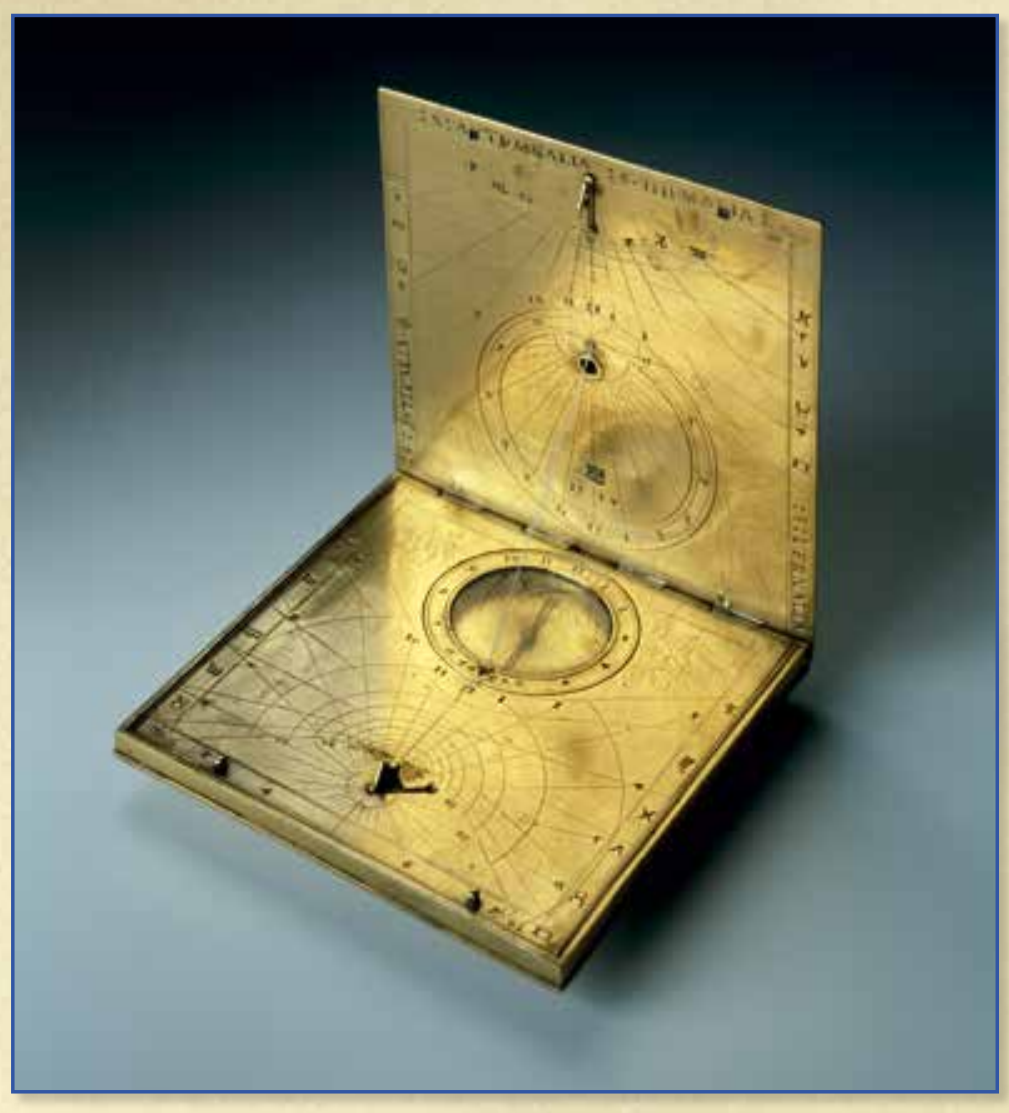

Time

Sense, Space, Structure

EDITED BY

Nancy van Deusen \& Leonard Michael Koff

B RILL

B R I L L 


\title{
Providence, Temporal Authority, and the Illustrious Vernacular in Dante's Political Philosophy
}

\author{
Jason Aleksander
}

One of the striking features of the metaphysics underpinning the dramatic elements of Dante's Divine Comedy may be seen by attending to the difference between the way in which the pilgrim and his interlocutors inhabit and perceive time. For instance, near the midpoint of Paradiso the pilgrim himself attests to this difference in a question posed to his ancestor Cacciaguida:

O cara piota mia, che sì t'insusi

che, come veggion le terrene menti

non capere in trïangol due ottusi,

così vedit le cose contingenti

anzi che sieno in sé, mirando il punto

a cui tutti li tempi son presenti:

mentre ch' io era a Virgilio congiunto

su per lo monte che l'anime cura

e discendendo nel mondo defunto,

dette mi fuor di mia vita futura

parole gravi, avvegna ch' io mi senta

ben tetragono ai colpi di ventura;

per che la voglia mia saria contenta

d'intender qual fortuna mi s'appressa,

ché saetta previsa vien più lenta.

Oh my dear root, who raises yourself so high that, as earthly minds see that two obtuse angles cannot fit in a triangle, so you see contingent things before they come to be, gazing at the point to which all times are present: while I was with Virgil upon the mountain that restores the souls and descending into the dead world, grave words were said to me about my future life, although I feel prepared well foursquare against the blows of events; so my will would be contented to understand what fortune approaches me, for the arrow foreseen comes more slowly. $\left[17.13^{-27}\right]^{1}$

1 Italian references to the La Divina Commedia follow the Edizione Nazionale sponsored by the Società Dantesca Italiana, ed. Giorgio Petrocchi (Milan, 1966-1967); this edition can be found

(C) KONINKLIJKE BRILL NV, LEIDEN, 2016 | DOI 10.1163/9789004312319_012 
In short, the pilgrim's interlocutors in Paradise see all contingent things in the temporal world's past, present, and future by gazing upon them sub specie aeternitatis. Dante's representations of the damned, too, are permitted a glimpse of the temporal world under the aspect of eternity, though for them the knowledge of either the temporal present in which the pilgrim's journey takes place or the eternal present of the divine mind is crucially absent. Thus, as John Freccero has put it in a recent essay devoted to canto 10 of Dante's Inferno, the damned only know a present that is granted to them by the presence of the pilgrim who, like the drink offered by Odysseus in Book XI of the Odyssey, "brings them to 'life' momentarily when their static existence intersects his human time." ${ }^{2}$

In one sense, then, in his interactions with those in Paradise or Hell, only the pilgrim has knowledge of the temporal present, and he is in motion in such a way that his motion marks time - a time that corresponds allegorically (as is generally recognized in the secondary literature) to the temporal death and resurrection of Christ. But while the pilgrim's cognition of time is that of a mortal human, the very fact that his conversations are with those for whom the phenomenology of time is quite different suggests that the metaphysics underlying the drama of the Commedia is a neo-Platonic one in which time is but the image of eternity. Indeed, the very geography of Paradise and Hell in the Commedia suggest why this must be the case. The damned, for their part, inhabit the concentric circles of the underworld. Their motions, if they are permitted any motion at all, are a mockery of the motions of the celestial spheres in that they are eternal but fruitless. The blessed, by contrast, do not even reside in the temporal world but, instead, inhabit the Empyrean beyond the boundaries of even the eternal motions of the celestial spheres in which the pilgrim first encounters them. Dante even draws explicit attention to this detail when, in Paradiso 4.28-48, he has Beatrice resolve the pilgrim's confusion regarding the reflected appearance of these blessed souls within the moving celestial spheres. According to her explanation, although all of the blessed truly inhabit the Empyrean (beyond time), they are reflected in specific celestial spheres according to an allegorical logic that signals the nature and extent of their spiritual exemplarity. In fact, perhaps the only souls that the Pilgrim encounters in his journey through the afterlife whose cognition of time resembles his are those purging themselves of sin on Mount Purgatory. The physical geography of this region, after all, differs from that of the other regions in two crucial respects:

online at both the Dartmouth and Princeton Dante Project websites. English translations are my own.

2 “Epitaph for Guido: 'Inferno' X," Religion and Literature 39/3 (2007), 1-29 (12). 
- Please check and approve the edit made of Running head.

(1) it is fundamentally an earthly geography in which the pilgrim's and the penitents' cognition of time is reinforced, for instance, by the apparent motion of the sun; and (2) the penitent motions of its inhabitants are fundamentally the mixed motions of a spiral (combining both circular and linear motion) as they travel both around the mountain and up to the summit.

Moreover, to the extent that one reads the Commedia as assuming the possibility of a human experience of happiness in the state described in Paradiso, the tension between the phenomenology of earthly time and its metaphysically imitative relationship to the reality of the eternal presence of the Divine - an eternal presence that is both in the temporal world and beyond it - fundamentally undergirds the allegorical purpose of the Commedia. On this reading, time is a feature of human fallenness. Consequently, it is only through the temporal striving for the Good that a human being becomes capable of receiving, through the grace of God, the eternal blessedness that would repair that fallen condition. Nevertheless, because the fallen world remains the image in the likeness of the eternal and unchanging model on which it is created, the cautious interpreter can read each specific fate of the damned, the penitent, and the blessed as indicative of the same providential ordering of human history; that is, each moment of every fate is a sign of the eternal presence of the divine in the world. Indeed, in Purgatorio 22, Dante, through his representation of the Roman poet Statius, suggests that, because of this providential ordering of human history, even a pagan poet like Virgil can guide others to Christianity:

Facesti come quei che va di notte, che porta il lume dietro e sé non giova, ma dopo sé fa le persone dotte, quando dicesti: "Secol si rinova; torna giustizia e primo tempo umano, e progenïe scende da ciel nova."

You did as one who goes at night, who carries the lamp behind and does not benefit from it, but teaches the people who follow when you said: "The age turns new; justice returns and the first human time, and a new progeny descends from heaven." $[67-72]^{3}$

3 Indeed, Purgatorio 21-22 suggest that Virgil's poetry has a greater capacity to guide others to Christianity than that of Statius, for even though Virgil is a pagan and lacks the faith that would be necessary for salvation, he was in life, unlike Statius, free of any moral defects (see Inferno 4.34-42). I discuss some of the philosophical implications of Dante's depiction of the 
That Virgil is able to do this even though he cannot himself attain spiritual salvation should not surprise the attentive reader since, for Dante, the greater one's intellectual capacity, the greater is one's ability to see in each and every creature and event the providential structure of history - thus representations of the souls of the damned and saved alike are, in the Commedia, signs of "quella fede che vince ogne errore" (that faith that vanquishes every error [Inferno 4.48]). It should not be surprising, therefore, that a poet of Virgil's ability and wisdom is able to grasp and signify a greater part of the truth than even that of which he himself is aware. Indeed, this conclusion is also suggested by Virgil's own comment that the merits of Homer, Horace, Ovid, and Lucan win them some (limited) degree of grace even in Hell (see Inferno 4.78).

In light of these brief glimpses of some of the Commedia's metaphysical presuppositions, this essay intends to explore how Dante's ethico-political philosophy operates within the crucial tension between the phenomenology of time as the condition for the possibility of human moral development and also as, metaphysically speaking, the privation and imitation of eternity. Rather than focus on the Commedia itself - a text which is structured by this tension in both its philosophical assumptions as well as the narrative and dramatic logic through which its fiction operates - this essay confines itself in what follows to a discussion of how Dante's understanding of time structures his ethico-political philosophy articulated in his three major philosophical treatises: De vulgari eloquentia, Convivio, and Monarchia. I will begin with a discussion of Dante's definition of the illustrious vernacular in De vulgari eloquentia: I will argue that Dante's understanding of the poetic and rhetorical function of the illustrious vernacular is tied to his political philosophy in a way that depends upon a rich but ultimately unresolved tension between (a) the demand that only an atemporal, unchanging vernacular would be suitable for the tasks of universal monarchy and (b) the recognition that only a temporal, localized, and changing illustrious vernacular could possibly bring about the existence of the universal monarchy.

In the second half of the essay, I will turn to Dante's treatment of the providential grounding for the independence of spiritual and temporal authority in Convivio and Monarchia: I will argue that Dante's understanding of divine providence provides common justification for the temporal and spiritual authorities whose independence he otherwise insists upon. Then, drawing on the letter to Cangrande della Scala (the authorship of which is disputed),

relationship between Virgil and Statius in "The Aporetic Ground of Revelation's Authority in the Divine Comedy and Dante's Demarcation and Defense of Philosophical Authority," Essays in Medieval Studies 26 (2010), 1-14. 
I will discuss how, for Dante, the providential ground for the legitimacy of temporal authority can only be discerned through the allegorical interpretation of history itself. In light of my discussion of these themes in Dante's political philosophy and its dependence on his understanding of divine providence, I will conclude with a brief reflection on how Dante's understanding of divine providence might help us better appreciate important aspects of the neglected legacy of Renaissance humanism in the history of early modern philosophy.

\section{Political Authority and the Illustrious Vernacular}

In Renaissance Humanism: Studies in Philosophy and Poetics, Ernesto Grassi points out that Dante's understanding of the nature of the illustrious vernacular harbors an indissoluble tension. On the one hand, Dante's political philosophy endorses the rule of a universal monarch who, "unlike the individual kings, rules the whole world, and whose task consists of preventing any alteration in the eternal order established and politically institutionalized by way of intellectual insight." ${ }^{4}$ Accordingly, Dante's philosophy of language requires for such a political state the possibility of a universal language that "in its universality and abstraction, avoids all local and temporal variations" (p. 7). Dante, however, also ascribes to the vernacular-poetic function of language the role of a tool necessary for concretely disclosing the "historical range of his nation" (p. 9) and for temporally bringing about the political unity of the universal monarch. In this section I will discuss why this tension arises in Dante's philosophy of language and how it depends upon Dante's understanding of the providentially guided unfolding of human history.

In De vulgari eloquentia, a work which was probably begun around 1302 and abandoned sometime around 1305, Dante defines vernacular language as

eam qua infantes assuefiunt ab assistentibus, cum primitus distinguere voces incipiunt; vel quod brevius dici potest, vulgarem locutionem asserimus, quam sine omni regula, nutricem imitantes, accipimus.

that which infants acquire from those around them when they first begin to distinguish sounds; or, to put it more succinctly, I declare that vernacular

4 Medieval \& Renaissance Texts and Studies 51, trans. Walter F. Veit (Binghamton, 1988), pp. 6-7. 
language is that which we learn without any formal instruction, by imitating our nurses. $[1.1 .2]^{5}$

Thus, vernacular language is distinguished from grammar, which is a "locutio secundaria" (secondary kind of language) possessed by the Romans and Greeks and others, "sed non omnes" (but not by all [1.1.3]). ${ }^{6}$ Unlike vernacular language, these grammars are a product of art and can only be acquired through the cultivation of a habitus in a dedicated study of its rules and doctrines (1.1.3). And also, as he explains in 1.9, unlike vernacular language, grammar

nichil aliud est quam quedam inalterabilis locutionis ydemptitas diversibus temporibus atque locis...nulli singulari arbitrio videtur obnoxia, et per consequens nec variabilis esse potest.

is nothing less than a certain immutable identity of language in different times and places... [and] subject to no individual will; and, as a result, it cannot change. [1.9.11]

In relation to this distinction, Dante argues in 1.1 for the superiority of the vernacular language - and here it will also help to note that Dante treats the modes of the vernacular as if they belong to a single species of language- - for three reasons:

Tum quia prima fuit humano generi usitata; tum quia totus orbis ipsa perfruitur, licet in diversas prolationes et vocabula sit divisa; tum quia naturalis est nobis, cum illa potius artificialis existat.

First, because it was the language originally used by the human race; second because the whole world employs it, though with different

5 Latin references are to De vulgari eloquentia, ed. Pier Vincezo Mengaldo (Padua, 1968). Translations are those of Steven Botterill (Cambridge, UK, 2005).

6 The term secundaria may imply in this context that it is a "second-rate" or "inferior" language as well as a kind of language that can only develop after one acquires a vernacular. One of the most common mistakes in interpretations of De vulgari eloquentia is to suppose that Dante believed that Romans and Greeks had only this secondary kind of language — that there were never Latin or Greek vernaculars. It seems clear to me, however, that Dante must recognize that there were Latin and Greek vernaculars before there were developed Latin and Greek grammars. In any case, as a matter of the logical claim here, Dante is saying that not all cultures have grammars, not that the Greeks and Romans only had grammars. 
pronunciations and using different words; and third, because it is natural to us, while the other is, in contrast, artificial. [1.1.4]

For Dante, despite the superiority of the vernacular over grammar, the very diversity of modes of the vernacular indicates its deficiency. Specifically, Dante argues that no existing mode of the vernacular is a language that, in any of its specific, municipal varieties — varieties that differ by convention-is perfectly equipped to produce or express virtues consistent with any of the ends of human nature. On behalf of this argument, Dante first appears to proceed empirically by means of a hunt for a perfect mode of the vernacular among roughly fourteen existing municipal forms of the Italian mode of the vernacular. Although I'll indicate below why we must regard this supposedly empirical hunt as a fantasy, it is worth noting a few of the deficiencies that he says mark the failures of existing municipal forms of the Italian mode of the vernacular. For instance, in 1.11, Dante judges the "tristiloquium" (vile jargon) of the contemporary inhabitants of Rome to be the "turpissimum" (ugliest) of all species of Italian expression and not even worthy of being called a vernacular. And, he adds, "nec mirum, cum etiam morum habituumque deformitate pre cunctis videantur fetere" (this should come as no surprise, for they also stand out among all Italians for the ugliness of their manners and their outward appearance [1.11.2]). Other local vernaculars fare little better. For instance, Dante writes that, when it comes to the Tuscans, it is evident that that their "turpiloquium" (foul jargon [1.13.3]) is little better than that of the Romans.

Dante's discussion of these Italian modes of the vernacular indicates two significant features of his philosophy of language. First, that Dante associates the vileness of custom with a corresponding deformity of the vernacular suggests that he also maintains that one's idiomatic language and one's ethicopolitical dispositions are highly correlated. Accordingly, for Dante the task of cultivating a virtuous person or a just state corresponds to the use of, or cultivation of, a virtuous mode of the vernacular. Second, what is significant about Dante's judgments regarding these modes of the vernacular (as well as the rules he provides in book two for the composition of poetry in the illustrious vernacular) is that he speaks on behalf of a universal authority, that is, as if he possesses an a priori knowledge of the underlying eternal form of the illustrious vernacular - when evaluating the aesthetic expression of the diverse existing modes of the vernacular. For instance:

Si quis autem quod de Tuscis asserimus de Ianuensibus asserendum non putet, hoc solum in mente premat, quod si per oblivionem Ianuenses amitterent $z$ licteram, vel mutire totaliter eos, vel novam reparare oporteret 
loquelam. Est enim $z$ maxima pars eorum locutionis: que quidem lictera non sine multa rigiditate profertur.

If there is anyone who thinks that what I have just said about the Tuscans could not be applied to the Genoese, let him consider only that if, through forgetfulness, the people of Genoa lost the use of the letter $z$, they would either have to fall silent for ever or invent a new language for themselves. For $z$ [constitutes] the greater part of their vernacular, and it is, of course, a letter that cannot be pronounced without considerable harshness. [1.13, translation altered.]

There is probably no reason to dispute Dante's characterization of the phonetic or ethical quality of the letter $z$, but the passage suggests two interesting questions that correspond with my observations above. First, why would a phonetic feature of a particular mode of the vernacular have anything to do with ethical considerations? Second, on what authority is Dante entitled to the judgment that an illustrious mode of the vernacular would not frequently include this phoneme? At the level of the question of the grounds for his competence as an authority ${ }^{7}$ capable of judging particular vernaculars Dante's argument can only be that the reason why any particular feature of a mode of the vernacular fails to produce or express the virtues pertinent to human ends is that it is a corrupted imitation of a timeless illustrious vernacular. However, as we shall see, it also turns out that the only noncorrupted imitation of this illustrious vernacular must itself be subject to local variation in response to the present needs of a particular political community.

In De vulgari eloquentia, Dante never explicitly makes such an argument. Consequently, to understand why this interpretation of Dante's philosophy of language is warranted requires beginning with a consideration of how he carries out his argument that the variability of municipal modes of the vernacular indicates their imperfection through a phylogenetic investigation of the origins of the modes of the vernacular language. In De vulgari eloquentia 1.3,

7 Albert Russell Ascoli's recent Dante and the Making of a Modern Author (Cambridge, UK, 2009) provides a masterful analysis of Dante's appeals to and transformations of a variety of traditional understandings of "authority." My own claims about Dante's conception of authority in this context are much more limited, and I am ultimately more concerned with Dante's philosophical understanding of the grounds of authority in aesthetic/political judgment than with the complicated rhetorical and dialectical processes through which Dante marshals and deploys this authority. 
Dante maintains that humans are defined by having been endowed with vernacular language since, unlike other animals and also unlike angels,

Oportuit ergo genus humanum ad comunicandas inter se conceptiones suas aliquod rationale signum et sensuale habere; quia, cum de ratione accipere habeat et in rationem portare, rationale esse oportuit; cumque de una ratione in aliam nichil deferri possit nisi per medium sensuale, sensuale esse oportuit.

So it was necessary that the human race, in order for its members to communicate their conceptions among themselves, should have some [sign] based on reason and perception. Since this [sign] needed to receive its content from reason and convey it back, it had to be rational; but since nothing can be conveyed from one reasoning mind to another except by means...[of] the senses, it had also to be based on [the senses]. [1.3.2, translation altered]

The endowment of the vernacular is thus interpreted as a divine gift since, "divinitus in nobis esse credendum est quod in actu nostrorum affectuum ordinato letamur" (we may believe that our joy in the ordered activity of our affects is of divine origin [1.5.2, translation mine]). And, according to Dante, this accords with the account of Genesis since the original human language, the language of Adam, was given to mankind by God so that human beings would be capable of glorifying "ipse qui gratis dotaverat" (He who had freely given so great a gift [1.5.2]).

This original vernacular, Dante claims, was a "certam formam locutionis a Deo cum anima prima concreatam fuisse" (certain form of language created by God along with the first soul [1.6.4]). It was spoken by Adam and by "omnes posteri eius usque ad edificationem turris Babel" (all his descendents until the building of the Tower of Babel [1.6.5]). And, had it not been for human presumption, "omnis lingua loquentium uteretur" (would have continued to be used by all speakers [1.6.4]). After the confusion, it was used only by the Hebrews, "ut Redemptor noster, qui ex illis oriturus erat secundum humanitatem, non lingua confusionis, sed gratie, frueretur" (so that our redeemer, who was to descend from them, insofar as He was human, should not speak the language of confusion, but that of grace [1.6.6]). According to this view, the cause of the imperfection and diversity of human language would not be the original fall from grace of Adam and Eve, but only the later hubris that had compelled Nimrod and his followers to construct the Tower of Babel. 
Specific aspects of the De vulgari eloquentia's discussion of language are later altered in Dante's treatment of the subject in the Commedia. For instance, in Paradiso 26, Adam himself explains that:
La lingua ch'io parlai fu tutta spenta innanzi che a l'ovra inconsummabile fosse la gente di Nembròt attenta.

The language that I spoke was entirely extinct before the people of Nimrod turned their attention to that unattainable work. [124-126, italics mine]

In light of this discrepancy, it may be that Dante simply "changed his mind," as Umberto Eco puts it, ${ }^{8}$ about the origins of the diversity of vernacular modes. It is, in any case, clear that the later view is that "born of humanity's natural disposition towards speech, languages may split, grow and change through human intervention. According to Adam, the Hebrew spoken before the building of the tower...was not the same as the Hebrew spoken in the earthly paradise" (Eco, p. 47).

But even though Eco is correct that Paradiso provides a different conclusion about the origins of the differentiation of the vernacular modes from each other, such a view is not at odds with the metaphysical presuppositions of $D e$ vulgari eloquentia. In the earlier work, as Eco is aware, Dante explains that the forma locutionis of the original vernacular is a form in respect to "quantum ad rerum vocabula et quantum ad vocabulorum constructionem et quantum ad constructionis prolationem" (words used for things, and to the construction of words, and to the arrangement of the construction [1.6.4]). Eco points out that this statement allows the inference that, "by forma locutionis, Dante refers to a lexicon and morphology and, consequently, a determined language" (p. 42). But while the De vulgari eloquentia seems to allow the interpretation that this "determined language" was spoken, as Hebrew, not only until the building of the Tower of Babel, but even afterwards, Eco insists that the text requires a more nuanced interpretation. According to Eco, when Dante writes "hac forma locutionis locutus est Adam" (In this form of language Adam spoke [1.6.5]), one must interpret Dante as suggesting that the activity of speaking "constructs" the Hebrew language not as a "determined language," but as a language that is temporally changing and so only contextually determinate as regards the

8 "The Perfect Language of Dante," in The Search for a Perfect Language, trans. James Fentress (Oxford, 1995), pp. 34-52. 
relationships between words and things. ${ }^{9}$ And, according to Eco, this interpretation is to be favored because, later in this same passage, Dante uses lingua rather than forma locutionis when speaking of the Hebrew spoken by Jesus. Moreover, such an interpretation is warranted by the final sentence of 1.6, where Dante writes that "Hebraicum ydioma illud quod primi loquentis labia fabricarunt" (the Hebrew language was that which the lips of the first speaker [fashioned]). ${ }^{10}$ In short, for Eco, the forma locutionis of the De vulgari eloquentia "was neither the Hebrew language nor the general faculty of language, but a particular gift from God to Adam that was lost after Babel. It is the lost gift that Dante sought to recover through his theory of an illustrious vernacular" (p. 43). Consequently, even though Paradiso offers what appears to be a different account of the origins of the municipal modes of the vernacular, both the Divine Comedy and the De vulgari eloquentia allow similar conclusions about the relationship of these modes of vernacular to the original forma lucutionis of the human vernacular.

Similarly, although I will confine my remaining remarks about the illustrious vernacular to a discussion of the De vulgari eloquentia, both it and the Divine Comedy allow the same conclusions about Dante's understanding of the role that an illustrious mode of the vernacular would play in political life. That is, both texts support the conclusion that, regardless of when human vernaculars became species differentiated by convention from the original, prepolitical forma locutionis, an "illustre, cardinale, aulicum et curiale" (illustrious, cardinal, aulic, and curial [1.16.6]) vernacular would be a mode of the vernacular that, in its lived, temporally changing modes of expression, approaches the perfection that pertains to the original forma locutionis. As Dante insists in De vulgari eloquentia 2.1-2, the illustrious vernacular ought not be used by all

Both "constructs" and "determined language," as terms employed in Fentress' translation of Eco's text, connote a modern understanding that may not be fully consistent with Dante's meaning. I have left these terms unaltered here and below when citing Eco's text. In relation to "determined language" it seems clear to me that Eco is speaking of a language in which there is an unchanging, universally determined relationship between word (verbum) and thing (res). In a temporal mode of the vernacular, however, the relationship between word and thing could not, according to Dante's argument, be determined universally/atemporally: because this relationship for temporal modes of the vernacular is structured by convention, it would be determinate only contextually.

10 Translation altered. In Fentress' translation of Eco's text, this sentence is rendered as follows: "It was thus the Hebrew tongue that was constructed by the first being endowed with speech" (p. 43). This translation is also consistent with the Latin sentence, and it correctly emphasizes the fact that Dante is not speaking of Hebrew as a forma locutionis but as a lived, temporally changing language. Here fabricarunt is translated as "constructed." 
writers, but only by those who possess both scientia et ingenium, ${ }^{11}$ that is, by those who possess both knowledge and genius (DVE 2.1.8). In the mouths of these rightful users, the illustrious vernacular would be a language that would express and produce the virtues that correspond to the tripartite aspects of a human soul: prowess in arms, which pertains to the vegetal part of the soul's determination to seek that which is useful; love, which pertains to a rectitude of the appetitive or animal part of the soul; and rectitude of will, which pertains to the rational part of the soul. That such a language can produce these virtues is precisely what Dante means in 1.17 when he calls such a language "illustrious" since such a language, by giving off light or reflecting the light it receives from elsewhere, is exalted by mastery and power, that is, the illustrious vernacular is equipped to rule because it is capable of changing human hearts so as to "nolentem volentem et volentem nolentem faciat" (make the unwilling willing and the willing unwilling [1.17.4]). And, in 1.18, he explains that such a language is cardinalis (cardinal or pivotal) because it "platant" (plants) what is best and peculiar to the local vernaculars and "extirpat" (removes) what is disreputable. It is "aulicus" (aulic or courtly) because "est ut omnibus sit comune nec proprium ulli" (it is common to all yet owned by none [1.18.2]). And it is "curialis" (curial) because it has been weighed by the scales of justice in a court unified either under the rule of a singular monarch (e.g., judged in a unified court such as that of the King of Germany) or, as is the case for the Italians, who lack a unified court in the former sense, according to a court unified "gratioso lumine rationis" (by the gracious light of reason [1.18.5]). This last criterion seems also to require that such a vernacular express what is necessary, that is, "what cannot be expressed otherwise" (Eco, p. 46), since: "quia curialitas nil aliud est quam librata regula eorum que peragenda sunt" (the essence of being curial is no more than providing a balanced assessment of whatever had to be dealt with [1.18.4]). To this extent, it would share with Adamic language the capacity to express a primordial affinity between word and thing.

It is in light, then, of Dante's discussion of the relationship between the illustrious vernacular and Adamic language that we can see in what sense Grassi was right to emphasize the tension between Dante's insistence that the authority of such a mode of the vernacular derives from its resemblance to an

11 Dante's use of the subjunctive in this context seems to me more than a bit misleading. When he asks whether all poets should be permitted to use this language, the question seems to imply that it would be possible for them to do so. But if the account that I am offering here is correct, it would in fact only be possible for those who ought to use such a language actually to do so. 
unchanging forma locutionis and, at the same time, his insistence that such a language function temporally as a political tool for bringing about the stable rule of a universal monarch. This tension between the universal, atemporal, transhistorical authority of an illustrious vernacular and its intrinsically localized context of signification ${ }^{12}$ constrains how Dante must address the question raised earlier concerning the grounds of his authority to judge the diversity of Italian municipal vernaculars. In the first place, "cardinality," for instance, would seem to be a criterion that establishes what is most just with respect to a particular context, that is, according to this interpretation, the cardinality of an illustrious vernacular would pertain not to its universal authority but to its suitability to produce justice in particular political contexts. Indeed, it is telling that in Dante's discussion of cardinality, the Bolognese receive the greatest admiration. He judges this municipal vernacular to be closest to an illustrious vernacular because it judges other Italian forms and appropriates what is best in them and dispenses with what is not. However, as will become clear, even in this instance, Dante implicitly maintains that such pivotal judgments about what to fetch and what to remove are possible only by reference to an underlying principle of universal authority.

I will discuss Dante's understanding of political authority in greater detail in the second half of this essay. However, even at this point in the discussion of his philosophy of language, it should be clear that his understanding of justice in its relation to the authority of a universal monarch departs significantly from Aristotle's understanding of justice as a virtue that can pertain only to a particular political constitution (it is worth noting that, for Aristotle, there are both just and unjust versions of different political constitutions). At the same time, however, Dante does acknowledge explicitly in Monarchia 1.14.5 that there must be variations of customs even within a universal monarchy. Thus, even where his political theory differs so markedly from Aristotle's, he nevertheless recognizes that even an illustrious vernacular must function in local contexts of signification that differ with respect to time and place.

A more revealing key to Dante's attitude about what grounds the authority to judge vernacular languages may be found in his selection of examples of those who write in a vernacular that most closely approaches the illustrious. All of the authors that Dante cites in a positive regard depart from the municipal vernacular that is native for them. More importantly, Dante explicitly draws

12 This tension is also discussed - to different ends-in Albert Russell Ascoli, "Neminem ante nos': Historicity and Authority in the De vulgari eloquentia," Annali d'Italianistica 8 (1991), 186-231; and Zygmunt G. Barański, “Significar per verba': Notes on Dante and Plurilingualism," The Italianist 6 (1986), 5-18. 
attention to the significance of his own exile as a feature pertinent to his ability to judge in the name of a universal authority:

Quicunque tam obscene rationis est ut locum sue nationis delitiosissimum credat esse sub sole, hic etiam pre cunctis proprium vulgare licetur, idest maternam locutionem, et per consequens credit ipsum fuisse illud quod fuit Ade. Nos autem, cui mundus est patria velut piscibus equor, quanquam Sarnum biberimus ante dentes et Florentiam adeo diligamus ut, quia dileximus, exilium patiamur iniuste, rationi magis quam sensui spatulas nostri iudicii podiamus.

Whoever is so misguided as to think that the place of his birth is the most delightful spot under the sun may also believe that his own languagehis mother tongue, that is - is pre-eminent among all others; and, as a result he may believe that his language was also Adam's. To me, however, the world is a homeland, like the sea to fish-though I drank from the Arno before cutting my teeth, and love Florence so much that, because I loved her, I suffer exile unjustly-and I will weight the balance of my judgment more with reason than with sentiment. [1.6.2-3]

In relation to the question of the universal grounds of authority, this comment suggests that the very condition for the possibility of evaluating diverse modes of the vernacular is "exile"13 or estrangement from any particular mode of the vernacular. Moreover, such an exile is also necessary for acquiring an illustrious mode of the vernacular since it would be impossible to acquire a perfect language within any particular political community already deformed by local, imperfect conventions. Thus, Dante's unjust exile from the imperfect community of Florence suggests a reversal of Adam's exile from Eden, an interpretation that is also justified by the fact that in this same section Dante proceeds from this comment on his own suitability to judge Italian vernaculars immediately to a discussion of the forma locutionis of Adamic language. ${ }^{14}$ From this, it

13 The significance of "exile" in Dante's philosophy of language receives extensive treatment in Marianne Shapiro's De vulgari eloquentia: Dante's Book of Exile (Lincoln, 1990).

14 Moreover, that Dante, out of love, suffers this exile from the imperfect (fallen) community also perhaps suggests a Christological feature of his thought on this point. If so, Dante's understanding of the possibility of reclaiming a perfect language is also clearly messianic (in the sense of Christian messianism): such a language would be a language appropriate only for a redeemed humanity and would require the unification of the ethical and spiritual ends of human existence. 
becomes clear that illustriousness, cardinality, courtliness, and curiality apply to the illustrious vernacular universally and independently of the conventions of a local political context. Or, put differently, the illustrious vernacular is a mode of the vernacular language that must function within a local political context in order to produce virtue in citizens through particular political conventions and habits, but its own authority to do so depends on or relates to that of universal political authority. In short, the illustrious vernacular could only be a language appropriate for a universal monarch who rules all local communities with the same authority, that is, the mode of the vernacular that corresponds most fully to the original, timeless and unchanging forma locutionis. Thus, beyond the aesthetic evaluations of specific defective features of the Italian modes of the vernacular noted earlier, the underlying principle according to which Dante judges all local modes of the vernacular as unequipped to produce or express the virtues pertinent even to earthly ends of human existence is that the illustrious vernacular must, in principle, serve the authority of the universal Monarch, and so, in each specific contemporary context, it must be whatever municipal mode of the vernacular that is most appropriate for the task of guiding a people to natural human felicity insofar as it is possible.

A last comment on the universality of this illustrious vernacular is in order, however. As I pointed out at the beginning of this section, Dante distinguishes between all vernaculars and all grammars in part on the basis of the mutability of all species of vernacular and the immutability of all species of grammar. That is, although the purpose and authority that underwrite the employment of an illustrious mode of the vernacular is itself unchanging — and so, in this sense, constitutes its authority over all human beings - the purpose of this authority to affect the will(s) of any of its subjects requires that the extrinsic manifestations of this vernacular be temporally subject to change. First, this illustrious vernacular must be local in its range of signification so that it is meaningful to those who hear it. Second, the actual signs employed by such a vernacular must also be mutable in relationship to the specific temporal needs of specific political communities, even of the specific temporal needs in a universal political community. In other words, the illustrious vernacular is whatever vernacular is used by one who is endowed with the ability to lead human beings from a condition of ethical and/or spiritual failure to a condition of ethical felicity and/or spiritual blessedness. In truth, then, the illustrious vernacular is an unchanging language only in the sense that, when it is employed by one capable of using it, the purpose and authority of linguistic expression is properly attentive to the universal needs of human nature. That is, the illustrious vernacular is the language used by one for whom the events of mundane history are recognized as the de jure unfolding of divine providence ordering 
all things in time toward the same universal end. Thus, this vernacular, like the manifestations of the souls of the blessed in the celestial spheres to which Beatrice refers in Paradiso 4, is accommodated to the specific needs of its audience in a particular time and place, but the authority of a speaker of such a language to deploy this vernacular is grounded in the speaker's understanding of the necessity of the unfolding of contingent events from an eternal, providential authority. In light of this recognition, then, I will discuss Dante's understanding of political authority in greater detail in the second half of this essay.

\section{Divine Providence as Grounds for Temporal Authority}

There are two fundamental principles that ground Dante's political philosophy: one is psychological, the other cosmological. The psychological principle, articulated succinctly in the last section of Monarchia, is that the human being, "solus inter omnia entia in duo ultima ordinetur, quorum alterum sit finis eius prout corruptibilis est, alterum vero prout incorruptibilis" (alone among all beings is ordered to two ultimate goals, one of them being his goal as a corruptible being, the other his goal as an incorruptible being [Monarchia 3.16.6]). ${ }^{15}$ This principle is sufficient for Dante's demonstrating the necessity of the independence of temporal and spiritual authority. However, for Dante the very fact that the human being is ordained to these two goals by its creator implies that his cosmological conception of divine justice is the more fundamental of the principles of his political philosophy. From this more fundamental principle, Dante derives the conclusion that temporal authority no less than spiritual authority derives from the providential unfolding through human history of divine justice in the world:

Cumque dispositio mundi huius dispositionem inherentem celorum circulationi sequatur, necesse est ad hoc ut utilia documenta libertatis et pacis commode locis et temporibus applicentur, de curatore isto dispensari ab Illo qui totalem celorum dispositionem presentialiter intuetur. Hic autem est solus ille qui hanc preordinavit, ut per ipsam ipse providens suis ordinibus queque connecteret. Quod si ita est, solus eligit Deus, solus ipse confirmat, cum superiorem non habeat.... Sic ergo patet quod auctoritas temporalis Monarche sine ullo medio in ipsum de Fonte universalis auctoritatis descendit.

15 All references to the Latin are from Prue Shaw's edition of the Cambridge Medieval Classics series (Cambridge, UK, 1995); translations are also Shaw's. 
And since the disposition of this world is a result of the disposition inherent in the circling of the heavens, in order that useful teachings concerning freedom and peace can be applied appropriately to times and places, it is necessary for provision for this protector to be made by Him who takes in at a glance the whole disposition of the heavens. For he alone is the one who preordained this disposition, making provision through it to bind all things in due order. If this is so, then God alone chooses, he alone confirms, since he has none above him. Thus it is evident then that the authority of the temporal monarch flows down into him without any intermediary from the Fountainhead of universal authority. [3.16.12-15]

In Convivio, an unfinished treatise composed circa $1304-1307^{16}$ in which he had also discussed these issues, Dante also makes clear why it is that he maintains that "non da forza fu principalmente preso per la romana gente, ma da divina provedenza, che è sopra ogni ragione" (this office, then, was obtained by the Roman people not principally by means of force, but by divine providence, which is the ultimate ground of all reason [4.4.11]). ${ }^{17}$ Dante advances this argument as a response to the hypothetical objection that the Roman emperorsthe paradigm for Dante's Emperor-obtained rule not by reason or right but by force. Dante's response, simply stated, is to admit that force may have been the instrumental cause that allowed for the establishment of Roman imperial authority, but that the moving or efficient cause was divine reason itself just as, by analogy,

16 De vulgari eloquentia was probably composed in 1303-1305, but was abandoned before its completion. There was probably some overlap between the periods in which Dante was working on both the De vulgari eloquentia and Convivio. In fact, there are some similar expressions between the two texts-e.g., the tripartite conception of the human soul as vegetal, animal, and rational (cf. De vulgari eloquentia 2.2 and Convivio 3.2). However, there are certainly important inconsistencies between the texts in certain specific areas. For a discussion of these, see Pier Vincenzo Mengaldo, Introduction and Notes to De vulgari eloquentia in Opere minori, tomo II, ed. P.V. Mengaldo et alia (Milan, 1979), pp. 6-7; Ileana Pagani, La teoria linguistic di Dante (Naples, 1982), pp. 152-54; and Stefano Rizzo, "Il De vulgari eloquentia e l'unità del pensiero linguistic di Dante," Dante Studies 87 (1969), 69-88. Nevertheless, both at a fundamental level and as pertaining to this essay, I believe that the Convivio and De vulgari eloquentia depend upon fundamentally compatible ethico-political philosophies and so permit a synthetic treatment of his philosophy of language and political philosophy.

17 Italian references to Convivio follow the Edizione Nazionale sponsored by the Società Dantesca Italiana, ed. Franca Brambilla Ageno (Florence, 1995); this edition can be found online at the Princeton Dante Project website. Translations are those of Christopher Ryan (Stanford, 1989). 
li colpi del martello cagione [instrumentale] del coltello, e l'anima del fabro è cagione efficiente e movente; e così non forza, ma ragione, [e ragione] ancora divina, [conviene] essere stata principio dello romano imperio.

the blows of the hammer are a cause of the knife, but the mind of the smith is the efficient or moving cause. So, too, reason not force, and indeed divine reason, must be regarded as the source of Roman rule or empire. [4.4.12 $]^{18}$

As evidence for this claim, Dante provides two arguments to show that this single providential structure is the common basis for the legitimacy of both temporal and spiritual authority. First, he argues that, after the fall of man, when God wanted "l'umana creatura a sé riconformare" (to refashion the human creature into a likeness of Himself once again 4.5.3), the earth had to become perfectly disposed for the coming of Christ, and this required two things: a political community, namely Rome, that would bring about this disposition and

una progenie santissima, della quale dopo molti meriti nascesse una femmina ottima di tutte l'altre, la quale fosse camera del Figliuolo di Dio: e questa progenie fu quella di David, del qual discese la baldezza e l'onore dell'umana generazione, cioè Maria.

a family-line of the highest sanctity, into which, after it had boasted many members of great virtue, would be born a woman surpassing all others, who would be the resting place of the Son of God. This was the line of David, from whom was born the joy and glory of the human race, Mary. [4.5.5]

Accordingly, human reason is able to discern in the coincidence of the birth of David and the arrival of Aeneas in Italy the fact of "la divina elezione del

18 In Monarchia, Dante claims that he, like the hypothetical interlocutor of the Convivio, once considered the matter only superficially and regarded the Roman people as having obtained their authority to rule over all not de jure but merely by force. "But," he states, "medullitus oculos mentis infixi et per efficacissima signa divinam providentiam hoc effecisse cognovi" (I penetrated with my mind's eye to the heart of the matter and understood through unmistakable signs that this was the work of divine providence [2.1.3]). 
romano imperio" (that the Roman empire was willed by God [4.5.6]). Second, claims Dante,

da Romolo cominciando, che fu di quella primo padre, infino alla sua perfettissima etade, cioè al tempo del predetto suo imperadore, non pur per umane ma per divine operazioni andò lo suo processo.

from the time of its founding father, Romulus, until the age of its highest perfection, under the above-mentioned emperor [Ceasar Augustus ${ }^{19}$ ], was the result of divine, not merely human, activity. [4.5.10]

After all, claims Dante, without God's direct involvement, it would be impossible to explain the moral uprightness of such an array of civically minded leaders (and Dante cites a number of examples that he believes justify this claim), as well as the fact that, for instance, the mere cackling of a goose could at one point save Rome "quando li Franceschi, tutta Roma presa, prendeano di furto Campidoglio di notte" (when the Franks, after capturing the whole of Rome, were on the point of capturing the Capitol by stealth under cover of darkness [4.5.18]).

In Monarchia, which was written sometime after $1314,{ }^{20}$ Dante reiterates these latter arguments: that the Romans placed public good above personal gain is discussed with similar examples in Monarchia 2.5; that a series of portentous events is evidence of divine providence is reiterated in Monarchia 2.4. But in Monarchia 2.6-11, Dante offers additional lines of argumentation. First, Dante argues that, since the judgment of God can be disclosed through contests between many striving for a single prize as well as through contests of strength between two champions, Rome's universal

19 For Dante, an explicit consequence of this argument is that not only was Rome chosen by God, but, since the world could only have been best prepared to receive Christ at the specific time of his coming, Rome must also have, at that time, secured the greatest degree of peace the world will know until, arguably, after the Last Judgment (see Convivio 4.5.7-8). Dante also reinforces this point in the Commedia where, in Justinian's account of the history of Rome, the following terzina refers to Augustus: "Con costui corse infino al lito rubro; / con costui puose il mondo in tanta pace, / che fu serrate a Giano il suo delubro" (With him it [Rome] raced to the Red Sea; with him it brought the world such peace that the temple of Janus was locked [Paradiso 6.79-81]). Commentators are unanimous in noting that, for Dante, Augustus shutting the gates of the temple of Janus for only the third time in the history of Rome is coincident with the birth of Christ.

20 For a summary of scholarly debates about the dating of the Monarchia see pp. xxxvii-xli of Prue Shaw's introduction to her Cambridge Medieval Classics edition of the Monarchia. 
authority is made manifest by its having won both an athletic contest among various rivals for "palmam monarchie" (the palm of monarchy [2.8.8, my translation]) as well as having won a duel between two champions. In the case of athletic competitions, Dante argues in 2.8 that while many (most notably Alexander of Macedonia) had sought to conquer the world, all failed but Rome. In the case of contests of strength between two champions, Dante argues in 2.9 that "Romanus populus per duellum acquisivit Imperium" (the Roman people acquired the empire through trial by combat 2.9.12]), and he cites many examples of such contests between champions decided in Rome's favor (for example, between Aeneas and Turnus, between the Romans and the Albans, between Scipio's forces and those of Hannibal, and so on). From both of these lines of argumentation, Dante concludes that Rome acquired rule not merely de facto but de jure and even states at the end of the section on duels that this "est principale propositum in libro presenti" (is our main thesis in this present book [2.9.21]). Also in both of these cases, Dante claims that he argues not from articles of Christian faith but from what he regards as "rationalibus principiis" (rational principles [2.10.1]) accepted by all people. Thus, in interpreting God's judgment, Christians as well as non-Christians are entitled to use the same evidence: Aeneas's victory over Turnus is of the same variety as David's over Goliath and Hercules' over Antaeus. The rationalia principia here is that in such contests, properly undertaken - for example, in a duel, both parties have to be seeking the same end, namely justice, and in an athletic contest both parties must abide by the same regulations-God's judgment, by whatever name it is recognized, ${ }^{21}$ becomes manifest.

While Dante claims that this first line of argumentation establishes Rome's de jure authority by rational principles, he presents additional lines of argument in Monarchia, 2.10-11, to prove Rome's authority "ex principiis fidei cristiane." In the first of these, Dante emphasizes especially that he seeks to undermine the arguments of those-by whom he means especially the popes and those who have supported them in the usurpation of secular authority ${ }^{22}$ — who regard themselves as "zelatores fidei cristiane" in their

21 "Pirrus 'Heram' vocabat fortunam, quam causam melius et rectius nos 'divinam providentiam' appellamus" (Pyrrhus called Fortune "Hera," that very cause we name, more correctly and righteously, "divine providence" [2.9.8]).

22

To some extent the argument may also have been targeted at a traditional, Augustinian understanding of the nature of just authority. Anthony Cassell suggests that "Dante's major concern in book 2, although he never names Augustine outright in this connection, is to mollify the anti-Roman negativity of that saint's treatise The City of God, that had narrowed 
having raged and meditated inane things against the "romanum Principatum" (2.10.1). The basic argument of these sections is that Christ himself sanctioned Rome's authority over all men. The first argument on behalf of this claim is that

Sub edicto romane auctoritatis nasci voluit de Virgine Matre, ut in illa singulari generis humani descriptione filius Dei, homo factus, homo conscriberetur: quod fuit illud prosequi.

Christ chose to be born of his Virgin Mother under an edict emanating from Roman authority, so that the Son of God made man might be enrolled as a man in that unique census of the human race; this means that he acknowledged the validity of that edict. $[2.10 .6]^{23}$

The second argument on behalf of the conclusion that Christ sanctioned the authority of Rome is slightly more complicated, but it would also perhaps have been more compelling for Dante's intended audience. In the final section of Monarchia 2, Dante argues that for Christ to have suffered for the sins of all mankind means that he had to be punished by an authority with jurisdiction over all mankind:

Et supra totum humanum genus Tyberius Cesar, cuius vicarius erat Pilatus, iurisdictionem non habuisset, nisi romanum Imperium de iure fuisset.

and transformed the primitive Christian acquiescence in the 'powers that be,' preached by both Christ and the Apostle Paul, into antagonism" (The Monarchia Controversy [Washington, D.C., 2004], p. 66). Put differently, Augustine does recognize an actual existence of two structures of authority in the world, but he denigrates the temporal authority as illegitimate whereas Dante argues for the providential grounds of temporal authority's legitimacy. But it should also be noted that Dante's disagreement with Augustine is not over the issue of providence, for as Cassell recognizes, Augustine, though he may have "derided the ancients for the idolatry that led them to a proud and obsessive pursuit of worldly glory through war and gore," also "proclaimed in City of God 5:21 that 'the Roman rule [Romanum regnum] was established by God, from whom all power comes, and by whose providence all things are ruled"' (p. 66, bracketed supplement in Cassell).

Dante pushes the argument even further in 2.10.7: "Et forte sanctius est arbitrari divinitus iliud exivisse per Cesarem, ut qui tanta tempora fuerat expectatus in sotietate mortalium, cum mortalibus ipse se consignaret" (And perhaps it is more holy to believe that the edict came by divine inspiration through Caesar, so that he who had been so long awaited in the society of men might himself be enrolled among mortals). 
And Tiberius Caesar, whose representative Pilate was, would not have had jurisdiction over the whole of mankind unless the Roman empire had existed by right. [2.11.5]

Anthony Cassell has addressed a number of these arguments in detail in The Monarchia Controversy. According to him, Dante's arguments concerning the de jure authority of Rome are, for the most part, validly constructed even if based on faulty or arbitrary premises. However, Cassell gives greater attention to the arguments from principles of faith regarding Christ's sanctioning the Roman Empire both by his birth and by his death. According to Cassell, these arguments rely on rhetorically persuasive enthymemes that suppress antecedents such as "the birth of Christ signified approval" and "whatever Christ suffered as punishment he approved" (Cassell, p. 79). Yet, even excepting these latter arguments of Monarchia, one has the sense that Cassell's basic attitude toward all of Dante's arguments concerning the nature of divine providence might best be summed up when he writes: "It is hard today not to see the poet's instances as preposterously quaint even while we inevitably admire the intensity of his personal persuasion. His arguments have, after all, nothing to do with claims of using the light of human reason or even of adducing credible authority" (p. 7o). ${ }^{24}$

While I do not wish to imply that I regard Dante's arguments as compelling (especially regarding the truth of the premises from which his demonstrations proceed), it is more important, for my purposes, to understand why Dante himself believed the arguments to be sound, especially in the cases of those arguments that Dante insists are constructed from "rational principles" rather than those he acknowledges to have been demonstrated from articles of Christian faith. Doing so, I believe, requires attending to the understanding of history subtending Dante's arguments. ${ }^{25}$

24 The comment is made specifically in relation to Dante's argument that portentous events signify the hand of God at work in the growth of Rome; however, I think the tone of the comment basically captures Cassell's attitude toward the majority of Dante's arguments about divine providence.

25 An alternative way to account for Dante's understanding of the soundness of his method of argumentation (which I shall not discuss in this essay) would involve examining, for instance, the discussion between the pilgrim and Saint Peter in Paradiso 24. In this canto, Dante is "tested" on the fundamentals of the nature of faith and its role in theological argumentation. He responds to Peter's question about why "faith" is regarded as a substance: "E io apresso: 'Le profonde cose / che mi largiscon qui la lor parvenza, / a li occhi di là giù son sì ascose, / che l'esser loro v'è in sola credenza, / sopra la qual si fonda l'alta spene; / e però di sustanza prende intenza. / E da questa credenza ci convene / silogizzar, 
As Jacob Klein has pointed out in his essay "History and the Liberal Arts," "the primary liberal disciplines listed by Dante in Convivio and linked to the ten heavens of the world...are Grammar, Logic, Rhetoric, Arithmetic, Geometry, Music, Astronomy, Physics and Metaphysics, Ethics, Theology. History is not one of them."26 Accordingly, Dante's understanding of the subject matter of history is certainly a pre-modern one. However, it would be a mistake to think that Dante has no distinct view about the subject matter of history. Rather, Dante's view of history resembles Aristotle's since, as Klein explains,

History in this sense is founded on completely 'unhistorical' points of view. That is why this kind of history writing does not constitute a specific domain like physics or even poetry. Note that Aristotle, the great systematizer of human knowledge, in the face of such history-the only one he knew-did not treat it as a pragmateia, a discipline in its own right. (p. 130)

According to such an understanding, Dante interprets the events of mundane or temporal history as symbols of the moral and spiritual development of humankind. Thus, for instance, "Troy and its destruction are symbols of man's pride and man's fall” (Klein, p. 132). ${ }^{27}$ And, to this extent, like Aristotle's understanding of history, Dante's history is, as Klein puts it, akin to history of the "pragmatic and genealogical kinds" (pp. 132-133), which are, in the case of pragmatic history, attempts to "measure the significance and importance of events" "by the desire to derive a lesson for the future either from mistakes and failures or from exemplary actions in the past" or, in the case of genealogical history, attempts to measure the significance and importance of events "by the consideration of the present state of affairs, the salient features of which want

sanz' avere altra vista: / però intenza d'argomento tene"” (And I responded: "The profound things that appear to me here, are so concealed from the eyes below that they exist in belief alone, and on that belief is founded the high hope; and therefore this belief refers to substance. And from this belief, without having another view, we must assent to syllogisms; therefore, it refers to argument" [70-78]). In short, Dante claims that faith, because it intends substance, may be utilized as a first principle in demonstrative arguments. Cf. Thomas Aquinas, Summa theologica II-II, q4, a1.

26 "History and the Liberal Arts", in Lectures and Essays, eds. Robert B. Williamson and Elliott Zuckerman (Annapolis, 1985), pp. 127-138 (133). In Convivio, see 2.13.

27 Although dramatic elements in the Divine Comedy support this interpretation insofar as speakers describe historical examples, an obvious confirmation of Klein's interpretation would seem to be the divinely-carved exempla of historical virtues and vices in Purgatorio 10 and 12. 
to be traced back to their origins" (p. 129). To the extent that history is employed in either of these ways, history is, according to Klein, understood to provide the pragmata relevant to narrating or symbolizing matters under consideration within another discipline (pragmateia), and this employment is especially pertinent with respect to the highest of the disciplines which are, by their nature, most distant from immediate experience.

Of these two modes of historical investigation, pragmatic history is especially pertinent to Dante's thought since, to quote Klein once again, "as far as pragmatic history is concerned, the selection is based on our sense of moral virtues or our understanding of practical maxims of conduct" (p. 130). History, in this sense, serves a practical end, and, in the disciplines of ethics and theology, it serves as the signs with which Dante, like his own guide Virgil, guides his readers to a state of ethical and spiritual perfection. In short, Dante's "history" is a tool of dialectical inquiry or rhetorical or poetic production, ${ }^{28}$ and it operates through allegorical interpretation. To the extent that Dante's view would permit history to function pragmatically not merely for ethics (which Aristotle allows) but also for theology (which Aristotle to some extent rejects-see, for instance, the last paragraph of Metaphysics $\Lambda .8$ ), his view would, of course,

28 For Dante, dialectical inquiry supplies first principles of a science since, following Aristotle, he maintains that "verum, quia omnis veritas que non est principium ex veritate alicuius principii fit manifesta, necesse est in qualibet inquistione habere notitiam de principio, in quod analectice recurratur pro certituine omnium propositionum que inferius assummuntur. Et quia presens tractatus est inquisitio quedam, ante omnia de principio scruptandum esse videntur in cuius virtute inferiora consistant" (since every truth which is not itself a first [that is, indemonstrable] principle must be demonstrated with reference to the truth of some first principle, it is necessary in any inquiry to know the first principle to which we refer back in the course of strict deductive argument in order to ascertain the truth of all the propositions which are advanced later. And since this present treatise is a kind of inquiry, we must at the outset investigate the principle whose truth provides a firm foundation for later propositions [Monarchia 1.2.4]). Thus, although Dante does not explicitly state that his inquiry is dialectical, his method is rooted in the rubric for this kind of inquiry laid out in the Topics, where Aristotle plainly states: "dialectic, being exploratory, is the path to the principles of every inquiry" (in Aristotle: Selected Works, 3rd edition, trans. and ed. Hippocrates Apostle and Lloyd Gerson [Grinnell, Iowa, 1991], A.2, 101b4). In discussing the letter to Cangrande della Scala and De vulgari eloquentia below, I will explain Dante's understanding of how a principle, once grasped, may subsequently guide productive (e.g., poetic or rhetorical) and practical (e.g., ethical, or political) activities. For now it suffices to note that, for Dante, when ruled by intellect (specifically, by the possession of a principle), poetic language and rhetoric may help produce desirable political ends such as a universal monarchy. Concerning Dante's familiarity with Aristotle's Organon, see Cassell, pp. 27-33. 
depart from Aristotle's. However, the more significant departure from Aristotle is not in mobilizing historical allegoresis on behalf of theology, but in the underlying understanding of the very activity of historical allegoresis.

Irrespective of its authenticity, the famous letter to Cangrande della Scala ${ }^{29}$ provides an important insight into Dante's understanding of the proper allegorical employment of history. In section 7 of this letter, the letter's author explains that, with respect to its service to practical ends, "history" must be understood in more than one way, for although various kinds of "sensus mystici variis appellentur nominibus, generaliter omnes dici possunt allegorici, cum sint a litterali sive historiali diversi" (mystical meanings are called by various names, they may one and all in a general sense be termed allegorical, inasmuch as they are different from the literal or historical, $§ 22$, emphasis mine).${ }^{30}$ In short, Dante's notion of history is, like his own Divine Comedy, "polysemos" (polysemous) in that its "primus sensus est qui habetur per litteram, alius est qui habetur per significata per litteram" (first meaning is that which is conveyed by the letter, and the next is that which is conveyed by what the letter signifies, $\S 20$ ). Accordingly, to the extent that the literal sense of the Divine Comedy is "status animarum post mortem simpliciter sumptus" (the state of the souls after death, pure and simple, § 24), the Divine Comedy's "history" records the placement of the souls of those who had died prior to approximately 1300, though it must be accepted that Dante regards such a literal sense, even if "historical," as fictive as well as poetic. ${ }^{31}$ But the allegorical "subject" of the Divine Comedy "est homo

29 The question of this letter's authenticity continues to be hotly debated. For recent discussions, see Robert Hollander's Dante's Epistle to Cangrande (Ann Arbor, 1993) and Seminario Dantesco Internazionale. International Dante Seminar 1, Proceedings of the First Congress at the Chauncey Conference Center, Princeton, October 21-23, 1994, ed. Z.G. Baranski (Florence, 1997). In any case, insofar as the letter is relevant to this essay, its arguments are roughly consistent with (though more detailed than) those offered in the first book of Convivio, so there is little reason for me to attempt any adjudication of the matter here.

$3^{0}$ Latin references and section numbers follow the Testo critico della Società Dantesca Italiana, ed. Ermenegildo Pistelli (Florence, 1960). This edition can be found online at the Princeton Dante Project website. Unless otherwise noted, translations are from Dantis Alagherii Epistolae, 2nd ed., ed. and trans. Paget Toynbee (Oxford, 1966).

31 On the various aspects of the allegorical form of the Commedia, see $\S 27$ of this letter. I see no reason to believe that Dante actually made a journey into the afterlife (nor, for that matter, to believe that Dante himself believed he had made such a journey, nor even that he believed he had received an epiphantic mystical vision). On the contrary, his "historical" narration must be regarded as fictive even if supporting a treatment that is also "definitive, analytical, probative, refutative, and exemplificative" (diffinitivus, divisivus, probativus, improbativus, et exemplorum positivus). In fact, this explains why Dante relates "encounters" with non-human or quasi-human souls who are known only through 
prout merendo et demerendo per arbitrii libertatem iustitie premiandi et puniendi obnoxius est" (is man as he is deserving of reward or punishment by justice according to merits or demerits in the exercise of his free will, $\S 25$ ). Thus, as the letter's author explains in section 39, "finis totius et partis est removere viventes in hac vita de statu miserie et perducere ad statum felicitates" (the aim of the whole and of the part is to remove those living in this life from a state of misery and to bring them to a state of happiness). And, as he explains in the following section, consistent with this finis, the branch of philosophy to which the Divine Comedy's history (in its allegorical employment) belongs is that of "morale negotium, sive ethica" (morals or ethics). ${ }^{32}$

In relation to this allegorical practice, the distance between Dante and Aristotle is therefore plain if we attend to a feature of Dante's argument that draws its force initially from a reference to Aristotle. In Convivio 4.5, as I have already noted, Dante explains that one of the best pieces of evidence that Rome was intended to rule by divine providence is that such a state of affairs would have most perfectly prepared mankind to receive Christ. Here Dante draws upon an argument he had made in Convivio 4.2.5 to the effect that, in order to understand matters properly, "quel tempo in tutte le nostre operazioni si dee attendere" (we should in all our actions wait for the right time). For Dante, this conclusion is explicitly warranted by the fact that Aristotle himself defines time in Physics $\Delta$ as "Numero di movimento secondo prima e poi,' e "numero di movimento celestiale" ("number of motion with respect to before and after," and "number of celestial movement," my translation), but which, according to Dante in the very same sentence, means that time "dispone le cose di qua giù diversamente a ricevere alcuna informazione" (disposes things here below to receive information in diverse ways [4.2.6, translation mine]).

But despite the ostensive references to Aristotle's Physics, there is a distinctly non-Aristotelian metaphysical understanding of human reason at work here. First, at the very beginning of Monarchia 2.6, the section in which Dante begins

myths (e.g., the "giants" of Inferno 31) as well as those who are known through historical or quasi-historical accounts and those whom Dante knew personally in his own lifetime.

Toynbee translates morale negotium as "morals" in this section and moralis neogtii as "ethics” in $\S 10$ ( $\$ 3$ in Toynbee's divisions). Given Klein's discussion of pragmateia above, note that, at the earlier instance of the term negotium, Toynbee explains: "negotium is the rendering in the Antiqua Translatio of the Ethics of the term $\pi \rho \alpha \gamma \mu \alpha \tau \varepsilon i \alpha$ " (n. 5, pp. 169-170). It should therefore be kept in mind that the connotations of both morales negotium and ethica are both different and somewhat broader in meaning than the English terms "morals" and "ethics" and that the author of the letter to Can Grande likely has in mind a philosophical "discipline" that involves the sorts of topics that are discussed in the Nicomachean Ethics. 
to lay out his "historical" arguments for the independence of Roman authority from the spiritual authority of the Church, Dante states:

Et illud quod natura ordinavit, de iure servatur: natura enim in providendo non deficit ab hominis providentia, quia si deficeret, effectus superaret causam in bonitate: quod est inpossibile.

Besides it is right to preserve what nature has ordained, for nature in the measures it takes is no less provident than man; if it were so, the effect would surpass its cause in goodness, which is impossible. [2.6.1]

Second, in Paradiso 27, Dante also makes clear that all motions (both temporal and eternal) are related to a single common measure in the movements of the Primum Mobile:

E questo cielo non ha altro dove che la mente divina, in che s'accende l'amor che 'l volge e la virtù ch'ei piove. Luce e amor d'un cerchio lui comprende, sì come questo li altri; e quel precinto colui che 'l cinge solamente intende. Non è suo moto per altro distinto, ma li altri son mensurati da questo, sì come diece da mezzo e da quinto.

And this heaven has no other where than the divine mind in which are enkindled the love that turns it and the power it rains down. Light and love encompass it in a circle just as it does the others; and that enclosure only the one who encloses understands. Its motion is not marked by another's, but from it the others are measured just as ten is from a half and a fifth. $[109-117]^{33}$

Moreover, in Convivio's discussion of the Primum Mobile, Dante claims that without this common measure for the motion of all the other spheres,

Non sarebbe quaggiù generazione né vita d'animale o di pianta; notte non sarebbe né die, né settimana né mese né anno, ma tutto l'universo sarebbe disordinato, e lo movimento delli altri sarebbe indarno.

33 This understanding of the "movement" of the Primum Mobile most resembles what Aristotle seems to have in mind when he discusses eternal motion. 
There would be no generation here below, either of animal or of plant life; there would be no night or day, or week or month or year, but rather all the universe would be disordered, and the movement of the other heavens would be in vain. [2.14.17]

Now, it would be more surprising if Dante, firmly in the tradition of Christian neo-Platonism, were not to associate the ends of Nature with the Good, however un-Aristotelian this may be. But what is relatively new ${ }^{34}$ in this formulation of history is a secularization of understanding of divine providence according to which history becomes a subject of allegorical interpretation in light of distinctly human ends. Put differently, for Dante, the order of nature and God's will are coextensive, and the mundane world is ordered in such a way as to prepare mankind for its moral and spiritual perfection. But the order of nature is understood by humans only in relation to their own distinct temporal and spiritual ends. Accordingly, Dante's understanding of history, by stressing the context through which all mundane events may be interpreted, requires a metaphysical grounding for the conclusion that what occurs naturally is "preserved" de jure and knowable through "rational principles."

It is not the practice of allegoresis that is new in the Renaissance, let alone in Dante's thought; rather, what is new in Dante's philosophy is that allegoresis, as applied to both the temporal and spiritual human ends, has turned from the objective representation of historical events to the subjective interpretation of the context of history. It is possible for Dante to reconstruct and interpret the past in such a way as to lead others to natural and supernatural perfection only to the extent that nature itself has prepared him in his own "proper moment" to understand its innermost causes. To one who is unprepared to understand the innermost causes of things, the events of mundane history might appear to be merely a de facto procession of chance. But to one who is properly disposed by history itself to understand the innermost causes of things, the events of mundane history are recognized as the de jure unfolding of divine providence ordering all things toward the same universal end.

It should now be clear why the enthymemes that Cassell regards as merely rhetorical or eristic in Dante's arguments regarding the evidence for divine providence have already, for Dante, been grounded by this peculiar understanding of history as a context of interpretation in which both the natural and the supernatural human ends can come to be unified and understood most

34 According to Walter Ullmann, Dante's predecessors in this regard would include Otto of Freising and William of Malmesbury (see Medieval Foundations of Renaissance Humanism [Ithaca, 1977], pp. 64-67). 
fully. So as long as one accepts the arguments that the significant and unique human ends are temporal and spiritual perfection, the historical evidence, however arbitrary it may seem, is ordered de jure in light of these ends. As a consequence, Cassell's judgment that Dante cannot reasonably expect his readers to accept an enthymeme involving a suppressed antecedent that Christ sanctioned his own crucifixion cannot be correct. To the contrary, it is all too clear that Dante does not regard, nor does he expect his readers to regard, such a premise as dubitable in any way. With respect to both temporal and spiritual ends, it is necessary that Christ did condone his own suffering and that the event is an expression of justice; otherwise one would have to deny what Dante assumes to be the inevitable truth that divine reason caused these events in order to make human perfection possible through its own nature. It is only when such events are abstracted from their precise order in nature, that is, abstracted from time itself, that they appear to be contingent and unjust.

\section{Conclusion}

In short, then, both Dante's political philosophy and his philosophy of language are tied to a common understanding of the nature of divine providence. Dante's political philosophy does not merely hold that divine providence is the common ground of both temporal and spiritual authority. Rather, Dante also maintains that the very grounds for the legitimacy of a sovereign can only be measured by one who attends to that sovereign's specific and local significance in the providential ordering of human history. Moreover, this understanding of political legitimacy is also embedded in Dante's philosophy of language since Dante's conception of the illustrious vernacular is constrained by the competing demands that it both help produce justice in a local environment and that it derive its authority from its universal suitability.

In light of these comments, then, it is clear that Dante's understanding of divine providence continually opens onto the aporetic relationship between the temporal function of the illustrious vernacular and its atemporally determined authority to perform this function. On the one hand, Dante explicitly maintains that the significance of singular historical events or the value of particular modes of expression can only be interpreted or judged in relation to their unique historico-political contexts. Moreover, he seems to acknowledge that conditions that might produce justice in one context are local, unique, and non-transferrable to another context. On the other hand, Dante persistently seeks a universal ground for the authority to judge and interpret these events and modes of expression. The principle that establishes such a jurisdiction is 
cosmological in that it understands history as the unfolding of particular contexts of signification in relation to divine providence. Thus the legacy of Christo-Platonism in Dante's thought is clearly expressed in the statement quoted above that the ultimate grounds for the legitimacy of human judgment "flows down... without any intermediary from the Fountainhead of universal authority" (Monarchia 3.16.15).

What is new, though, in Dante's understanding is the way in which this providential ground for secular authority operates in relation not only to the spiritual ends of the human being but also in relation to the earthly ends of human nature. Or, in other words, Dante seems to embrace a tension between two major modes in the prior history of philosophy. On the one hand, he embraces elements of an Aristotelian ethico-political philosophy that emphasizes the importance of the temporal ends of human activity and that to some extent undermines the significance of divine providence in legitimizing those activities. On the other hand, he is also deeply committed to a Christo-Platonic psychology and metaphysics in which a predominant conception of the role of divine providence makes very few concessions to the legitimacy of historical and cultural differentiation.

In light of this tension within his thinking, I would like to close by suggesting that, with respect to later philosophies of history that might bear some resemblance to Dante's peculiar understanding, what may be considered distinctly "modern" is: (a) that Dante understands history as a realm of inquiry in which the significance of mundane events is interpreted in relation to the total context of history in which they are embedded and (b) that, for Dante, such an interpretation is made possible only by virtue of a universal metaphysical principle that secures a common measure in relation to which these events may be judged. For Dante, this common measure is itself always linked to the particular point of view of the individual for whom it is appropriate to interpret history allegorically or, what may be the same thing, to produce virtue in others through poetic expression. It may therefore be appropriate to think that Dante's understanding of the proper grounds for individual authority might also be viewed as a prototype of the modern "subject" since the principles by which such an individual authority judges are authoritative for that subject only to the extent that they are, in principle, common to all by nature. 